\begin{tabular}{|l|l|l||}
\hline \multicolumn{2}{|c|}{ PublisherInfo } \\
\hline \hline PublisherName & $:$ & BioMed Central \\
\hline \hline PublisherLocation & $:$ & London \\
\hline \hline PublisherImprintName & $:$ & BioMed Central \\
\hline \hline
\end{tabular}

\title{
Adding insult to injury
}

\begin{tabular}{|l|l|l||}
\hline \multicolumn{2}{|c|}{ ArticleInfo } \\
\hline \hline ArticleID & $:$ & 4828 \\
\hline \hline ArticleDOI & $:$ & $10.1186 /$ gb-spotlight-20030815-01 \\
\hline \hline ArticleCitationID & $:$ & spotlight-20030815-01 \\
\hline \hline ArticleSequenceNumber & $:$ & 180 \\
\hline \hline ArticleCategory & $:$ & Research news \\
\hline ArticleFirstPage & $:$ & 1 \\
\hline \hline ArticleLastPage & $:$ & 3 \\
\hline \hline & & RegistrationDate : 2003-8-15 \\
\hline ArticleHistory & $:$ & OnlineDate \\
\hline \hline ArticleCopyright & $:$ & BioMed Central Ltd2003-8-15 \\
\hline \hline ArticleGrants & $:$ & \\
\hline \hline ArticleContext & $:$ & 130594411 \\
\hline \hline
\end{tabular}




\section{Cathy Holding}

Email: cholding@hgmp.mrc.ac.uk

Some genetic diseases do not follow a simple pattern of inheritance and exhibit phenotypic variation. This can be explained as a monogenic disorder that is being affected by the action of nonlinked genetic modifiers. A molecular mechanism by which phenotypic variation in disease severity occurs is reported by David Buchner and colleagues at the University of Michigan School of Medicine in the August 15 Science. A mutation in the neuronal sodium channel gene $S c n 8 a$ results in neurological disease in mice, but the severity varies from progressive but survivable in resistant strains to lethal in susceptible strains, prompting the team to search for a molecular mechanism to account for this in a region they previously mapped to mouse chromosome 3. Comparison of the mouse DNA sequence with the equivalent human region identified a single stop codon mutation that reverse transcription polymerase chain reaction analysis showed to result in both normal and mutant transcripts (Science 2003, 301:967-969.

Buchner et al. observed that the transcript lacked an exon and that the two abnormal proteins predicted occurred in the susceptible strains. Susceptible mice were rescued with transgenic wildtype sequence, with the abundance of correctly spliced $S c n 8 a$ transcripts comparable with that found in the mice of the resistant background. Analysis of protein domains of the $S c n 8 a$-modifying gene revealed zinc finger motifs that placed the transcript into the U1C subfamily of RNA-binding proteins commonly found in RNA-processing proteins, known to be involved in splicing. This modifying gene, sodium channel modifier 1 (SCNM1), is widely expressed in mouse embryonic and adult tissues, suggesting that the molecule could also effect genome-wide changes in pre-mRNA processing.

"The effect of genetic background on the severity of inherited disorders has long been recognized, but only a few modifiers have been molecularly identified to date... The role of human SCNM1 in modulating splicing defects can now be tested with the use of linkage markers on human chromosome $1 \mathrm{q} 21, "$ the authors conclude.

"Many disease mutations in humans and other species disrupt pre-mRNA splicing and a rapidly growing body of evidence shows that various aspects of RNA biology, including splicing, are common targets of phenotypic modifiers... The Buchner study is perhaps the best-characterized example of a modifier and target gene in mammals, and similar studies are likely to follow," writes Joseph Nadeau at Case Western Reserve University in an accompanying article.

\section{References}


1. University of Michigan School of Medicine, [http://www.med.umich.edu/medschool/]

2. Science, [http://www.sciencemag.org/]

3. Case Western Reserve University, [http://www.cwru.edu/] 